getting lower every year, and world never again attain the level that they once had according to the traditions of past generations. It should be added that the springs were at their highest about the commencement of this month, and are now gradually falling.

Hoddington House, Odiham, March $3 \mathbf{I}$

P. L. SClater

\section{Scorpion Suicide}

I AM sorry that my experiments on scorpion suicide has given pain to some of your correspondents. Allow me to explain in a few words the object of my investigation. It is commonly believed in this colony and elsewhere that scorpions commit suicide; Dr. Allen Thomson, in a letter to NATURE, lent the weight of bis scientific name to this view; and Dr. G. J. Romanes, in his "Animal Intelli-rence," treats it as an open question. Now if this habit of comnitting suicide be an established fact, we have in scorpions a highly persistent type of creature that inherits a habit detrimental alike to the individual and the species. Scorpion suicide, therefore, if a fact, is one of the strongest individunl cases against the Theory of Evolution by Natural Selection that is presented to us in the animal kingdom. It seemed to me that the only way of settling this questi n u as by the direct appeal to experiment. But is the Theory of Natural Selection of : ufficient importance in its bearing upon buman life and buman progress to justify the infliction of / ain upon, say, sixty scorpions? I am one of those who believe that it is. I am one of those who believe that the theory of evolution has enormously influenced human thought and action, and is destined to influence it in a constantly increasing degree. I believe that much of the moral and intellectual progress of our race is indissolubly associated with this theory of evolution. I may be wrong in that opinion, but that is the opinion I hold. And holding that opini in it became to me a duty to do sometbing towards settling a question which seemed to me to be of great importance in its bearing on the evolution theory. And it was my object to do the work, as far as I cuuld, thoroughly and once for all. I believed that if I could show that even under torture scorpions do not commit suicide, the view that they do so u hen irritated by the bright light of a candle-flare became highly improbable. To establish a negative in the face of positive assertions is, however, difficult, and I considered it necessary to experiment upon a number of individuals. Hinc illa lachryma! One of my fritnds, however, protested as follows : "The theory of evolution," he said, "is now so strongly established, that scorpion suicide is a priori impossible." But I hold it to be dangerous in the extreme, in the present po-ition of science, to set up the theory of evolutior as a ductrine from which to draw deductions, unshecked by an appeal to nature where such appeal is possible.

Rondibosch, March 12

C. LLOYD MORGAN

\section{Nesting Habits of the Emu}

I AM able fully to confirm Prof. Moseley's statement of the habits of the emu in nesting at Blenheim. Some years ago my father was very successful in rearing these birds at his place at Brockham Lodge, near Dorking. The first eqg was usually laid shortly after Christmas; the total number of a brood being from fifteen to twenty, laid usually at intervals of about forty-eight hours. Some time before the full number nas laid the cock bird would comnence the incubation by carefully driwing them under him. When the hen bird was ready to add to their nuwher she would sit down by his side, produce the egg, and her mate would then carefully draw it under him with his foot. As sron a, the number was completed, it became necessary to seclude the hen lird, as she was from this time "vicious" towards her mate and towards her own egys; and the seclusion continued until the young birds had attained a considerable size, as she showt d every disposition to destroy them. The number of eggs laid was ofien too large for the cock bird to get comfortably under him. Still during several years that my father kept the birds a considerable sumber of eggs were aunually hatched, and the young $t$ irds reared to th: breeding age. No brood from native birds was, however, obtained. 'I hey showed no disposition to change the breeding season from January to July. In captivity the birds strikingly exhibited their :ingular inquisitive propensities. They were not $u$ ually vicious, except during the breeding : eas'sn, but were very easily frightened.

London, March $3 \mathbf{I}$
ALFRED W. BENNETT

\section{The Recent Cold Weather}

THE excessively severe and prolonged cold weather of the month of March has bardly a parailel in this century. It appears to have been felt throughout Europe, and has even reached the shores of Africa. Frost, snow, and wintry gales we expect at a season proverbial for its fitful severity, but the scarcely interrupted sweep of the frivid atmospheric waves which have overwhelmed us for three successive weeks is an experience of weather so remarkable that I conceive the record will probably interest some of your readers.

In position, altitude, and in its freedom from the sheltering influence of large towns, this station may be accepted as favourable for giving an accurate account of the weather in the centre of England. Our instruments are on a proper meteorological stand, and are by Negretti and Zambra. I may add that, in its blighting influence on vegetation stimulated into activity by a mild and moist period in Fehruary, this weather has proved more destructive to early fruit blossoms, certain shrubs and plants accepted as hardy, than from any weather previously experienced in March in other years; but apart from vegetation, and acting on the upturned fallows and soddened clods of clay, the penetrating winds, frequent frosts and falls of snow have pulverised the land, so that it falls before the plounh or harrow like calcined limestone, and in respect to the preparation of land the weather has had a beneficial action.

\begin{tabular}{|c|c|c|c|c|c|c|c|c|c|c|c|c|}
\hline March & & Min. & & Max. & & Grass. & & Wind. & & Rain. & & Snow. \\
\hline 4 & $\cdots$ & 27 & $\ldots$ & 50 & $\cdots$ & 27 & $\ldots$ & & $\cdots$ & 一 & $\cdots$ & - \\
\hline 5 & $\cdots$ & 27 & $\ldots$ & $5^{I}$ & $\ldots$ & 20 & $\ldots$ & N. & $\ldots$ & - & $\cdots$ & $\overline{-}$ \\
\hline 6 & $\ldots$ & 33 & $\ldots$ & $5^{2}$ & $\ldots$ & 29 & $\cdots$ & N. & $\ldots$ & - & $\ldots$ & $0^{\prime \prime} \cdot 2$ \\
\hline 7 & $\cdots$ & 26 & $\cdots$ & 40 & $\cdots$ & 22 & $\ldots$ & N. & $\ldots$ & - & $\ldots$ & $\mathrm{o}^{\prime \prime} \cdot 2$ \\
\hline 8 & $\ldots$ & 24 & $\ldots$ & $4 \mathrm{I}$ & $\ldots$ & 24 & $\ldots$ & & $\cdots$ & 一 & $\ldots$ & $\mathrm{o}^{\prime \prime} \cdot 25$ \\
\hline 9 & $\ldots$ & 20 & $\ldots$ & 35 & $\ldots$ & 14 & $\ldots$ & & $\ldots$ & 一 & $\ldots$ & $0^{\prime \prime} \cdot 12$ \\
\hline I0 & $\ldots$ & 9 & $\ldots$ & 37 & $\ldots$ & 4 & $\ldots$ & 1 & $\ldots$ & 一 & $\ldots$ & $0^{\prime \prime} \cdot 5$ \\
\hline I I & $\ldots$ & 20 & $\cdots$ & $3^{8}$ & $\cdots$ & I0 & $\cdots$ & N. & $\ldots$ & - & $\cdots$ & \\
\hline 12 & $\cdots$ & 25 & $\ldots$ & 39 & $\ldots$ & 23 & $\ldots$ & N.W. & $\ldots$ & - & $\ldots$ & $0^{\prime \prime} \cdot 2$ \\
\hline I3 & $\cdots$ & 25 & $\ldots$ & 39 & $\ldots$ & 20 & $\ldots$ & W & $\ldots$ & -- & $\ldots$ & $o^{\prime \prime} \cdot I$ \\
\hline 14 & $\cdots$ & 29 & $\cdots$ & $4^{\circ}$ & $\cdots$ & 22 & $\ldots$ & W & $\cdots$ & - & $\cdots$ & \\
\hline I 5 & $\ldots$ & 27 & $\ldots$ & 39 & $\ldots$ & 20 & $\cdots$ & N. & $\ldots$ & - & $\ldots$ & $0^{\prime \prime} \cdot 5$ \\
\hline I6 & $\ldots$ & 26 & $\ldots$ & $3^{8}$ & $\ldots$ & 19 & $\ldots$ & W.S.W. & $\cdots$ & - & $\cdots$ & \\
\hline I 7 & $\ldots$ & 28 & $\ldots$ & $3^{8}$ & $\ldots$ & 24 & $\ldots$ & S.V & $\ldots$ & - & $\ldots$ & $\mathrm{o}^{\prime \prime} \cdot 9$ \\
\hline 18 & $\ldots$ & 25 & $\ldots$ & $4^{\circ}$ & $\cdots$ & 20 & $\ldots$ & $\mathrm{s}$ & $\ldots$ & - & $\ldots$ & $\mathrm{O}^{\prime \prime} \cdot \mathrm{I}$ \\
\hline I9 & $\ldots$ & 28 & $\ldots$ & $4^{2}$ & $\ldots$ & $2 \mathrm{I}$ & $\ldots$ & $\mathrm{N}$ & $\ldots$ & 一 & $\ldots$ & $\mathrm{o}^{\prime \prime} \cdot \mathrm{r}$ \\
\hline 20 & $\ldots$ & $3^{I}$ & $\ldots$ & 40 & .. & $3^{I}$ & $\ldots$ & E. N.E. & $\ldots$ & - & $\ldots$ & $0^{\prime \prime} \cdot 31$ \\
\hline $2 \mathrm{I}$ & $\ldots$ & $3^{2}$ & $\ldots$ & 37 & $\ldots$ & $3^{I}$ & $\ldots$ & N.E. & $\ldots$ & - & $\cdots$ & \\
\hline 22 & $\ldots$ & 28 & $\ldots$ & 35 & $\cdots$ & 27 & $\ldots$ & $\mathrm{E}$ & $\ldots$ & - & $\ldots$ & \\
\hline 23 & $\ldots$ & 28 & $\ldots$ & 35 & $\ldots$ & 26 & $\ldots$ & N.E. & $\ldots$ & - & $\cdots$ & \\
\hline 24 & ... & I8 & $\ldots$ & $4^{2}$ & $\ldots$ & 5 & $\ldots$ & W & $\ldots$ & - & $\ldots$ & - \\
\hline 25 & $\cdots$ & 26 & $\ldots$ & 45 & $\ldots$ & I6 & $\cdots$ & N.: & $\ldots$ & $\mathrm{O}^{\prime \prime} \cdot 4$ & $\cdots$ & \\
\hline 26 & & 26 & $\ldots$ & $4 \mathrm{I}$ & $\ldots$ & I9 & $\ldots$ & N.) & $\ldots$ & $0^{\prime \prime} \cdot 5$ & $\ldots$ & - \\
\hline 27 & $\cdots$ & 27 & $\ldots$ & $4^{\circ}$ & .. & I8 & $\ldots$ & N. & $\ldots$ & - & $\cdots$ & \\
\hline 28 & & 26 & $\ldots$ & 43 & $\ldots$ & 16 & $\ldots$ & N.V & $\ldots$ & - & $\ldots$ & \\
\hline 29 & $\ldots$ & 24 & $\ldots$ & $4 \mathrm{I}$ & $\ldots$ & 12 & $\ldots$ & & $\ldots$ & $\overline{-}$ & $\ldots$ & \\
\hline 30 & $\ldots$ & 35 & $\cdots$ & 48 & $\cdots$ & 35 & & S. & $\cdots$ & $0=3$ & & \\
\hline & $\ldots$ & 30 & $\ldots$ & 55 & $\ldots$ & & & & $\cdots$ & O.II & $\cdots$ & \\
\hline
\end{tabular}

Belvoir Castle Gardens

WILLIAM INGRAM

\section{Sap-Flow}

A REMARKABLE instance of the strong up-rush of sap in trees at ihis time of the yec $r$ occurred here during the late severe weather. The boughs of a sycamore overhanging a road were trimmed on the $2 \mathrm{Ist}$ of this mon!h during a very keen frost, and next day icicles of frozen sap, varying in length from a couple of inches to a foot, were hanging from the severe $i$ ends. The icicles were semi-o/aque in appearance and slightly iridescent, like the sheen on the moonstone, and, when put in a bottle and melted, the product was pure sap.

The sycamore, being one of the earliest trees to develop leaves, had its sap rising, notwithstanding the intense cold and late season; while a beech, which is much later in coming out, and an ash, which is usually latest of all, wh sse boughs bad also been lopped, showed no signs of bleeding, and the cuts remained dry and bare.

The icicles have been melted, reformed, and melted again since the $2 \mathrm{Ist}$, and still the sap is dropping from the cuts.

Highfield, Gainsborongh, March 28 